\title{
Rumen bacterial community profile and fermentation in Barki sheep fed olive cake and date palm byproducts
}

\author{
Alaa E Rabee ${ }^{\text {Corresp., } 1}{ }^{,}$, Khalid Z. Kewan ${ }^{1}$, Ebrahim. A Sabra ${ }^{2}$, Hassan. M. El Shaer ${ }^{1}$, Mebarek Lamara ${ }^{3}$ \\ ${ }^{1}$ Animal Production, Desert Research Center, Matariya, cairo, Egypt \\ ${ }^{2}$ Genetic Engineering and Biotechnology Research Institute, University of Sadat City, sadate city, Menoufia, Egypt \\ 3 Forest research institute, University of Quebec in Abitibi-Temiscamingue, Rouyn-Noranda, Canada \\ Corresponding Author: Alaa E Rabee \\ Email address: alaa.bakr.stu@gebri.usc.edu.eg
}

Rumen bacteria make the greatest contribution to rumen fermentation that enables the host animal to utilize the ingested feeds. Agro-industrial byproducts (AIP) such as olive cake $(O C)$ and date palm byproducts (discarded dates (DD), and date palm fronds (DPF)) represent a practical solution to the deficiency in common feed resources. In this study, thirty-six growing Barki lambs were divided into three groups to evaluate the effect of untraditional diets including the AIP on the growth performance. Subsequently, nine adult Barki rams were used to evaluate the effect of experimental diets on rumen fermentation and rumen bacteria. Three rations were used: common concentrate mixture (S1), common untraditional concentrate mixture including $\mathrm{OC}$ and DD (S2), and the same concentrate mixture in S2 supplemented with roughage as DPF enriched with $15 \%$ molasses (S3). The animals in S2 group showed higher dry matter intake (DMI) and lower relative growth rate (RGR) as compared to the animals in S1 group. However, the animals in S3 group were the lowest in DMI but achieved RGR by about $87.6 \%$ of that in the $\mathrm{S1}$ group. Rumen $\mathrm{pH}$, acetic and butyric acids were more prevalent in animals of S3 group and rumen ammonia (NH3$\mathrm{N})$, total volatile fatty acids (TVFA), propionic acid were higher in S1. Rumen enzymes activities were higher in S1 group followed by S3 and S2. The bacterial population was more prevalent in S1 and microbial diversity was higher in the S3 group. Principal coordinate analysis revealed clusters associated with diet type and the relative abundance of bacteria varied between sheep groups. The bacterial community was dominated by phylum Bacteroidetes and Firmicutes; whereas, Prevotella, Ruminococcus, and Butyrivibrio were the dominant genera. Results indicate that diet S3 supplemented by OC, DD, and DPF could replace the conventional feed mixture. 


\section{Rumen bacterial community profile and fermentation in}

3 Barki sheep fed olive cake and date palm byproducts

5 Alaa Emara Rabee ${ }^{1}$, Khalid. Z Kewan ${ }^{1}$, Ebrahim. A Sabra², Hassan. M. E1 Shaer ${ }^{1}$, Mebarek

6 Lamara $^{3}$

$7 \quad{ }^{1}$ Animal and Poultry Nutrition Department, Desert Research Center, Cairo, Egypt

$8{ }^{2}$ Animal Biotechnology Department, Genetic Engineering and Biotechnology Research Institute,

9 University of Sadat City, Sadat City, Egypt

$10{ }^{3}$ Forest research institute, University of Quebec in Abitibi-Temiscamingue, Rouyn-Noranda,

11 Canada

12

Corresponding Author:

14 Alaa Rabee

15 Animal and Poultry Nutrition Department, Desert Research Center

16 1Mathaf El Matariya St.B.O.P.11753

17 Matariya, Cairo, Egypt

18 Email: rabee_a_m@yahoo.com

19 Mobile: +201096884139 ; fax: +20226357858 


\section{Abstract}

43 Rumen bacteria make the greatest contribution to rumen fermentation that enables the host

44

45

46

47

48

49

50

51

52

53

54

55

56

57

58

59

60

61

62

63

64

65

66

67

68

69

70

71

72

73

74

75

76

77

78

79

80

animal to utilize the ingested feeds. Agro-industrial byproducts (AIP) such as olive cake (OC) and date palm byproducts (discarded dates (DD), and date palm fronds (DPF)) represent a practical solution to the deficiency in common feed resources. In this study, thirty-six growing Barki lambs were divided into three groups to evaluate the effect of untraditional diets including the AIP on the growth performance. Subsequently, nine adult Barki rams were used to evaluate the effect of experimental diets on rumen fermentation and rumen bacteria. Three rations were used: common concentrate mixture $(\mathrm{S} 1)$, common untraditional concentrate mixture including OC and DD (S2), and the same concentrate mixture in S2 supplemented with roughage as DPF enriched with 15\% molasses (S3). The animals in S2 group showed higher dry matter intake (DMI) and lower relative growth rate (RGR) as compared to the animals in S1 group. However, the animals in S3 group were the lowest in DMI but achieved RGR by about $87.6 \%$ of that in the $\mathrm{S} 1$ group. Rumen $\mathrm{pH}$, acetic and butyric acids were more prevalent in animals of S3 group and rumen ammonia (NH3-N), total volatile fatty acids (TVFA), propionic acid were higher in S1. Rumen enzymes activities were higher in S1 group followed by S3 and S2. The bacterial population was more prevalent in S1 and microbial diversity was higher in the S3 group. Principal coordinate analysis revealed clusters associated with diet type and the relative abundance of bacteria varied between sheep groups. The bacterial community was dominated by phylum Bacteroidetes and Firmicutes; whereas, Prevotella, Ruminococcus, and Butyrivibrio were the dominant genera. Results indicate that diet S3 supplemented by OC, DD, and DPF could replace the conventional feed mixture.

Keywords: Barki sheep, rumen, bacteria, Illumina Mi Seq, olive cake, date palm by products

\section{Introduction}

The dramatic increase in animal feed prices encouraged nutritionists to search for cheaper alternatives to the traditional feedstuffs (Al-Dabeeb, 2005). Locally available byproducts such as agricultural and industrial byproducts could be a suitable solution to reduce the cost of animal feeding (Estaún et al., 2014) as the ruminant animals can utilize the high-fiber diets (Alnaimy et al., 2017). Palm date and olive trees are grown mainly in hot countries in the Middle East and Africa where Egypt is the main producer of date palm worldwide (Almitairy et al., 2011; Awawdeh and Obeidat, 2013; Khattab et al., 2018). Olive fruit processing for oil production generates large quantities of olive cake (OC) that has a negative environmental impact; therefore, many studies proved its potential as a part of animal diets (García-Rodríguez et al., 2020). On the other hand, various types of residues are produced from date palm trees such as discarded dates (DD) that are generated from dates processing and date palm fronds (DPF) that are generated from tree pruning (Almitairy et al., 2011; Allaoui et al., 2018). DD are characterized by high energy content and palatability for animals; therefore, it is a suitable alternative for conventional cereals in animal diets (Almitairy et al., 2011). However,

PeerJ reviewing PDF | (2021:08:65038:1:0:NEW 11 Oct 2021) 
81 both OC and DPF are considered as fibrous materials, and low in protein content and high in

82

83

84

85

86

87

88

89

90

91

92

93

94

95

96

97

98

99

100

101

102

103

104

105

106

107

108

109

110

111

112

113

114

115

116

117

118

119

120

phenolic compounds like tannins that could depress rumen fermentation and modulate rumen microbiota (Mahgoub et al., 2007; Mioč et al., 2007; Khattab et al., 2018; Mannelli et al., 2018; García-Rodríguez et al., 2020). Different studies indicated that those byproducts might replace a part of the concentrates feed mixture (Al-Dabeeb, 2005; Estaún et al., 2014; Khattab et al., 2018). Nevertheless, limited information regarding their effect on rumen microbiota is available (Mannelli et al., 2018; García-Rodríguez et al., 2020).

The rumen is inhabited by various microbial communities, including bacteria, fungi, protozoa, archaea, and viruses, which enable the ruminant animal to utilize the ingested feed (Gilbert et al., 2020). Bacteria dominate the rumen microbial communities and make the greatest contribution to rumen fermentation (Kim et al., 2015). It can ferment a wide range of substrates in animal diet including, cellulose, xylan, amylose, and protein and produce volatile fatty acids and microbial protein that provide the host animal with a large proportion of daily protein and energy requirements (Henderson et al., 2015; Rabee et al., 2020b). The composition and density of rumen bacteria are highly influenced by diet composition (Henderson et al., 2015) as the diet modulates the rumen fermentation patterns and $\mathrm{pH}$ (Carberry et al., 2014). Subsequently, diets with high-cellulose and hemicellulose stimulate the fibrolytic bacteria, while concentrates feed mixture rich in starch and soluble sugars stimulate amylolytic bacteria (Carberry et al. 2012). Therefore, improving strategies to understanding the rumen microbiome could maximize animal productivity (Lee et al., 2012; Rabee et al., 2020b).

Analysis of rumen microbiome using high throughput sequencing technologies has expanded our understanding of rumen microbial communities (Jami et al., 2014). The adoption of these techniques helped to explore the variation in microbial communities due to changing the animal diet or geographic location (Henderson et al., 2015). However, the final output could be biased due to the DNA extraction method, PCR-primer, sequencing platform, and bioinformatics pipeline (Henderson et al., 2013; Rabee et al., 2020b). Therefore, it is highly recommended to link rumen microbiota, functional genes, metabolic pathway, rumen metabolites, and animal performance (Denman et al., 2018; Li et al., 2019).

The Barki sheep is a small breed that has white wool and a brown neck and is distributed in the desert in the Mediterranean zone; also, it has long thin legs that allow travel for long distances in search of grass (Elshazly et al., 2019). This breed is well adapted to survive in harsh conditions, including poor feeding, heat stress, and diseases (Abdel-Moneim et al., 2008). The Barki sheep is the main sheep breed in Egypt's desert; it provides meat and milk under desert conditions; thus, it represents an important food supply in Egypt (Abousoliman et al., 2020). Despite the economic importance of Bakri sheep in Egypt, the rumen microbiome did not receive attention in comparison to other domesticated ruminants. Ruminant production in the Mediterranean countries is challenged by poor quality and scarcity of pastures especially during the drought periods besides the increase in cereal prices (Elshazly and Youngs, 2019). Therefore, it is important to develop new strategies to improve animal efficiency using locally available resources (Romero-Huelva et al., 2012). Feeding systems that depend on OC, DD, and DPF are

PeerJ reviewing PDF | (2021:08:65038:1:0:NEW 11 Oct 2021) 
121 common in arid countries including Egypt; besides, several studies interested in the effect of

122 inclusion of olive cake and date palm byproducts on animal performance and rumen

123 fermentation (Estaún et al., 2014; Khattab et al., 2018). However, there is still limited

124 information on the impact of these residues on the rumen microbiome. Mannelli et al. (2018)

125 incorporated olive cake into the diet of lactating ewes and observed that the relative abundances

126 of some bacterial taxa have been affected. On the other hand, no data were available on the effect

127 of date palm byproducts on rumen bacteria. Additionally, no previous reports studied the effect

128 of rations including OC, DD, and DPF on animal performance, rumen fermentation, and rumen

129 bacteria. Therefore, the objective of this study was to evaluate the effect of common

130 untraditional feeding systems that based on OC, DD, and DPF on the growth performance,

131 rumen fermentation, and rumen bacteria community of Barki sheep.

\section{Materials \& Methods}

\section{Growth trial}

134 Growth trial was conducted at a commercial private farm in Matrouh government as a part of

135 project "The Executive Project for Breeding and Production Systems Development of Camel and 136 Small Ruminant in the Northwest Coast of the Arab Republic of Egypt" that was funded by the

137 Arab Center for Studies of Arid Zones and Arid Lands (ACSAD). The project was conducted 138 and supervised by the Desert Research center, Egypt. Thirty-six growing male Barki lambs with 139 an average body weight of $29.65 \pm 0.29 \mathrm{~kg}$ (mean $\pm \mathrm{SE}$ ) were randomly divided into equal three 140 groups and housed in 12 well-ventilated shaded pens as three replicates in each group (3 $141 \mathrm{lambs} / \mathrm{pen})$. The animals were assigned to one of three treatments and received ad lib diets for 75 142 days and free access to drinking water was provided. The experimental rations were: control 143 ration or common concentrate mixture (S1); non-traditional concentrate mixture including $10 \%$ 144 olive cake (OC) and 60\% discarded date palm (DD) (S2); the same concentrate ration in S2 145 supplemented with ground date palm fronds (DPF) enriched with $15 \%$ molasses as roughage 146 (S3). The physical composition of the experimental rations is presented in Table 1. Lambs were 147 weighed biweekly until the end of the experiment. At the end of the growth trail, the animals 148 were left on the farm without euthanizing.

149 Digestibility and rumen fermentation trials

150 Nutrients digestibility and rumen fermentation trials were conducted at Maryout Research 151 station, Desert Research center, Egypt. Nine adult Barki rams with an average body weight of $15255.10 \pm 1.47 \mathrm{~kg}$ (Mean $\pm \mathrm{SE}$ ) were assigned into three groups ( 3 animals/ treatment) to evaluate 153 the impact of experimental diets on the digestibility of DM, CP, and NDF as well as 154 investigation of rumen fermentation and composition of rumen bacterial community.

155 Animals were adapted for the diet in individual metabolic cages for 15 days, followed by 7 days 156 as a collection period. Drinking water was offered free before the collection period and two times 157 during the collection period. Daily collected feces were subsampled and dried at $70^{\circ} \mathrm{C}$ for $48 \mathrm{~h}$, 158 159 then grounded and conserved until analysis. On day 22, rumen liquid was collected using a stomach tube before the morning feeding and the $\mathrm{pH}$ of rumen fluid was immediately recorded 
160

161

162

163

164

165

166

167

168

169

170

171

172

173

174

175

176

177

178

179

180

181

182

183

184

185

186

187

188

189

190

191

192

193

194

195

196

197

using a digital $\mathrm{pH}$ meter (WPA CD70). Rumen samples were used for the analyses of rumen ammonia and VFA, DNA extraction, and lignocellulolytic enzymes assays.

This study, including the growth trail and digestibility trail, was conducted under guidelines set by the Department of Animal and Poultry Production, Desert Research Center, Egypt. Moreover, the project was approved by the Institutional Animal Care and Use Committee, Faculty of Veterinary Medicine, University of Sadat City, Egypt (Reference: VUSC00008). All methods were performed in compliance with the ARRIVE guidelines. In addition, the project does not include euthanasia of the experimental animals. The sample size was decided based on the availability of animals that are similar in age, weight, physiological stage.

\section{Chemical analyses}

The experimental diets were analyzed for dry matter, crude protein (CP), and crude fiber (CF) according to AOAC, (1997). Neutral detergent fiber (NDF) and acid detergent fiber ADF contents were determined by the method of Van Soest et al. (1991) without sodium sulfite. Dry fecal samples were analyzed for CP and NDF. Moreover, the rumen ammonia and total VFA concentrations were determined by steam distillation in a Kjeldahl distillation according to the methods of Annison (1954) and AOAC, (1997), respectively. In addition, individual VFAs were measured using high-performance liquid chromatography (HPLC) (Weimer et al., 1991). Additionally, cellulase and xylanase activities were determined by quantifying the released reducing sugars by the 3, 5- dinitrosalicylic acid (DNS) (Ghose, 1987; Bailey et al., 1992). Xylanase was measured as endo-xylanase that was defined as the amount of enzyme that releases $1 \mu \mathrm{mol}$ of xylose per $\mathrm{ml}$ in a minute. Cellulase was quantified as a unit of endo- $\beta-1,4$-glucanase that is defined as the amount of enzyme that could hydrolyze filter paper and release $1 \mu \mathrm{mol}$ of glucose within 1 min of reaction.

\section{DNA Extraction, PCR amplification, and sequencing}

One milliliter of rumen fluid was centrifuged at $13000 \mathrm{rpm}$ and the precipitated pellets were used for DNA extraction by i-genomic Stool DNA Extraction Mini Kit (iNtRON Biotechnology, Inc.) according to the manufacturer's instructions. DNA was then eluted in $50 \mu \mathrm{L}$ elution buffer and DNA quality and quantity were verified using agar gel electrophoresis and Nanodrop spectrophotometer (Thermo Fisher Scientific, Madison, Wisconsin, USA). DNA Amplicon libraries targeting the V4-V5 region of the 16S rRNA bacterial 16S ribosomal DNA gene were generated by PCR amplification using primers 515F (5'-GTGYCAGCMGCCGCGGTAA-3') and 926R (5'-CCGYCAATTYMTTTRAGTTT-3') (Walter et al. (2015). PCR amplification was conducted under the following conditions: $94^{\circ} \mathrm{C}$ for $3 \mathrm{~min} ; 35$ cycles of $94^{\circ} \mathrm{C}$ for $45 \mathrm{~s}, 50^{\circ} \mathrm{C}$ for $60 \mathrm{~s}$, and $72^{\circ} \mathrm{C}$ for $90 \mathrm{~s}$; and $72^{\circ} \mathrm{C}$ for $10 \mathrm{~min}$. PCR products' purification, preparation for sequencing using Illumina MiSeq system were conducted according to the protocol described by Comeau et al. (2017) in Integrated Microbiome Resource (Dalhousie University, Canada). 
198 Quantitative real-time PCR (qPCR)

199 Real-time PCR was conducted to determine the total bacterial 16S rRNA copy number in the

200

201

202

203

204

205

206

207

208

209

210

211

212

213

214

215

216

217

218

219

220

221

222

223

224

225

226

227

228

229

230

231

232

233

234

rumen fluid. Standards were generated using dilutions of purified genomic DNA from Prevotella sp, Ruminococcus albus, Butyrivibrio hungatei purchased from DSMZ (Braunschweig,

Germany). Dilution series of the standards ranging from $10^{1}$ to $10^{6}$ copies of the 16S rRNA gene were used. The qPCR was performed using the Applied Biosystems StepOne system (Applied Biosystems, Foster City, USA).

The bacterial specific primers F (5'-CGGCAACGAGCGCAACCC-3') and R (5'CCATTGTAGCACGTGTGTAGCC-3') (Denman and McSweeney, 2006) were applied to amplify DNA samples and diluted standards. The $10-\mu \mathrm{L}$ reaction consisted of $1 \mu \mathrm{L}$ genomic DNA, $1 \mu \mathrm{L}$ of each primer, and $7 \mu \mathrm{L}$ SYBER Green qPCR- master mix (iNtRON Biotechnology, Inc.). The PCR conditions were as follows: 40 cycles of $95^{\circ} \mathrm{C}$ for $15 \mathrm{~s}$, and $60^{\circ} \mathrm{C}$ for $60 \mathrm{~s}$. The linear relationship between the threshold amplification $(\mathrm{Ct})$ and the logarithm of 16S rDNA copy numbers of the standards was used to calculate the copy numbers of rumen bacteria per $\mu \mathrm{L}$ of DNA.

\section{Bioinformatics analyses}

The bioinformatics analyses of the paired-end (PE) Illumina raw sequences were processed in $\mathrm{R}$ (version 3.5.2) using DADA2 (version 1.11.3) (Callahan et al., 2016). Briefly, reads will be denoised, dereplicated and filtered for chimeras to generate Amplicon Sequence Variants (ASVs). Taxonomic assignment of sequence variants was compared using the latest SILVA reference database SILVA. The resulting ASV table was normalized and subsequently used to perform downstream analyses, including the computing of alpha and beta diversity metrics and taxonomic summaries.

\section{Statistical analysis}

The statistical analyses were conducted using the IBM SPSS version 20 software (SPSS, 1999). The differences in feed intake, relative growth rate, rumen fermentation parameters, rumen enzymes, bacterial copy number, microbial diversity, and relative abundance of bacterial phyla and genera were performed using one-way ANOVA based on a post hoc Duncan test. For all statistical tests, $p$-values $<0.05$ were considered significant. The results of relative abundance of bacteria were tested for normality using Shapiro-Wilk test and non-normal values were then arcsine transformed. All the sequences were deposited to the sequence read archive (SRA) under the accession number: PRJNA744569

\section{Results}

\section{Chemical Composition of the experimental diets}

The composition and chemical analysis of animal diets are presented in Tables 1 and 2 . The results indicated that olive cake and discarded date palm represented $70 \%$ of the untraditional concentrates mixture (S2). Moreover, the traditional concentrates mixture (S1) contained higher 
235

236

237

238

239

240

241

242

243

244

245

246

247

248

249

250

251

252

253

254

255

256

257

258

259

260

261

262

263

264

265

266

267

268

269

270

271

content of CP and NDF compared with S2. Whereas, S2 contained higher content of DM, CF, and ADF compared with S1.

\section{Performance of growing lambs}

The results of dry matter intake (DMI), organic matter intake (OMI), and the relative growth rate (RGR) are presented in Table 3. The differences in DMI and RGR were significant among groups. Animal group S2 consumed the highest total DMI followed by S1 and S3, respectively. Both S2 and S3 groups showed a comparable RGR value but they are lower than that revealed in the $\mathrm{S} 1$ group.

\section{Digestibility of nutrients in adult rams}

Sheep group S2 showed the highest total DMI followed by S3 and S1, respectively (Table 3). The untraditional diets (S2 and S3) showed lower values for CP and NDF digestibility as compared to the traditional diet (S1).

\section{Rumen fermentation parameters and lignocellulolytic enzymes}

The effect of ration type on rumen fermentation parameters and enzymes assays are presented in Table 4. The ration S3 that containing DPF resulted in a higher rumen $\mathrm{pH}$ value followed by S2 and then S1; and rumen ammonia concentration followed the same trend. Both S2 and S3 showed significantly lower total VFA concentration but higher in acetic and butyric fractions as compared with S1. However, the ration S1 was superior in propionic acid fraction.

S1 group showed higher values for rumen xylanase and cellulase production as compared with the other two groups but still without significant differences (Table 4). The bacterial population (Log10 of 16S rDNA copies) was significantly affected by the experimental rations. The copy number was higher in the S1 group followed by S3 and then S2, respectively (Table 4).

\section{Rumen bacterial diversity analysis}

Following quality filtering, merging and removal of chimeric sequences, the sequencing of the V4 region on 16S rDNA in rumen samples from nine sheep resulted in 196999 high-quality sequence reads with an average of $21888 \pm 1113$ reads per animal (Mean \pm Standard error; SE) (Table 5). Alpha diversity metrics were used to estimate the similarity in the bacterial community among sheep groups. The bacterial richness was estimated using Chao and ACE indices. Moreover, the bacterial diversity was determined using Invsimpon and Shannon indices. The sheep group fed S3 diet showed higher ASVs number and alpha diversity indices compared to $\mathrm{S} 2$ and $\mathrm{S} 1$ groups with a significant difference in Shannon index. The principal coordinate analysis (PCoA) based on Bray-Curtis dissimilarity (Figure1) used to estimate beta diversity of bacterial communities within sheep groups confirmed that sheep groups were separated distinctly from each other.

\section{The composition and relative abundance of bacterial community}

A total of 14 bacterial phyla were detected and the bacterial community was dominated by phylum Bacteroidetes (76.2\%) and Firmicutes (19.9\%) and other phyla found to be less than 
272 1.5\% (Table 6). The relative abundance of bacterial phyla varied between sheep groups. Phylum

273 Bacteroidetes dominated the bacterial community in sheep rumen and it was higher in the S3

274 (78.7\%) group compared to S1 (75.8\%) and S2 (74.1\%) (Table 6 and Figure 2). This phylum was

275 dominated by four families, including Rikenellaceae, and Prevotellaceae. Family Rikenellaceae

276 showed the highest proportion in the $\mathrm{S} 2$ group and was dominated by RC9_ gut group. In

277 addition, family Prevotellaceae was higher in S1 group with a significant difference and most of

278 the family's reads were assigned to genus Prevotella and uncultured Prevotellaceae.

279 Phylum Firmicutes was the second largest phylum in sheep rumen, it was significantly higher in

280 the S1 group (22.7\%), followed by S2 (22.1\%), and S3 (15\%) (Table 6 and Figure 2). This

281 phylum was dominated by five families, including Veillonellaceae, Erysipelotrichaceae,

282 Ruminococcaceae, Lachnospiraceae, and Family_XIII. While group S2 showed the highest

283 representation of family Lachnospiracea, the sheep group S1 diet showed the highest

284 representation of Veillonellaceae, Erysipelotrichaceae, and Ruminococcaceae. Furthermore,

285 Family_XIII was higher in S3. In addition, phylum Firmicutes was dominated by five genera,

286 including Selenomonas, Ruminococcus, Butyrivibrio, Megasphaera, and Sharpea. These genera

287 were also affected by diet type; Selenomonas was higher in S1group followed by S3 and S2,

288 respectively. Butyrivibrio was higher in S2 followed by S3 and S1 respectively (Table 6 and

289 Figure 2).

290 Sheep in the S3 group showed higher proportions of phylum Proteobacteria, Fibrobacteres,

291 Planctomycetes, Tenericutes, Cloacimonetes, Elusimicrobia, Kiritimatiellaeota,

292 Verrucomicrobia, Synergistetes, and Lentisphaerae. Whereas group S1 showed higher

293 proportions of phylum Spirochaetes, and Actinobacteria and the differences between the groups

294 were significant $(\mathrm{P}<0.05)$ in the relative abundance of Fibrobacteres, and Elusimicrobia (Table

295 6).

296 Some genera were observed exclusively in specific groups such as Bifidobacterium

297 (Actinobacteria) and Lactobacillus (Firmicutes), Schwartzia (Firmicutes), Dialister (Firmicutes),

298 and Catenisphaera (Firmicutes) that were observed in S1. Additionally, genus Papillibacter

299 (Firmicutes), found only in R3 and Kandleria (Firmicutes) found only in the S2 group.

\section{Discussion}

301 Chemical composition of diets

302 Physical and chemical characteristics of animal diet are the main driver of modulations in the

303 rumen microbiome (Denman et al., 2018); therefore, understanding the rumen microbiome could

304 lead to developing strategies to improve animal productivity (Wirth et al., 2018). Agricultural

305 byproducts provide suitable alternatives to the common feedstuffs in the arid countries (Mioč et

306 al., 2007; Awawdeh and Obeidat, 2013; Allaoui et al., 2018). However, those byproducts should

307 be evaluated on the level of their effect on animal performance and the rumen ecosystem

308 (Alnaimy et al., 2017). To the best of our knowledge, this study is the first to report the effect of

309 using untraditional diets that contain a combination of olive cake and date palm byproducts

310 (discarded date or dates palm fronds) in sheep feeding on animal performance, rumen

311 fermentation, and rumen bacteria (Table 1). The common concentrate feed mixture is a starchy

Peer] reviewing PDF | (2021:08:65038:1:0:NEW 11 Oct 2021) 
312 mixture and has low-fiber content and high content of crude protein, energy, and soluble 313 carbohydrates (Carberry et al., 2012). At the same time, olive cake and date palm fronds are 314 described as low-quality feedstuffs with high contents of lignocelluloses and low contents of 315 protein and energy (Awawdeh and Obeidat, 2013; Boufennara et al., 2016; García-Rodríguez et 316 al., 2020). Furthermore, the discarded dates are considered as an energy source due to high 317 soluble carbohydrates and contain low crude protein (Al-Dabeeb, 2005; Boufennara et al., 2016; 318 Allaoui et al., 2018).

\section{Animals' performance}

320

321

322

323

324

325

326

327

328

329

330

331

332

333

334

335

336

337

338

339

340

341

342

343

344

345

346

347

348

349

350

351

In this study, the highest DMI was obtained by group S2, which fed feed mixture contains OC, and DD; while the lowest DMI was obtained by group S3, which fed feed mixture contains OC, and DD plus DPF (Table 3), this finding in line with a study by Rajabi et al. (2017), when discarded dates included in sheep's diet. De Visser et al. (1998) indicated that the inclusion of the late cut grass with high-fiber content decreased the DMI. The higher DMI in S2 could be attributed to the palatability of diet contains DD or rapid passage rate (Khezri et al., 2017; Iqbal et al., 2019).

Untraditional CFM diet alone (S2) or supplemented with date palm fronds (S3) resulted in low relative growth rate ( 54.43 vs. $57.78 \%$, respectively) but the highest value was recorded for the $\mathrm{S} 1$ group $(66.02 \%)$ that fed common feed mixture (Table 3). The decline in growth rate in S2 and $\mathrm{S} 3$ diets could be attributed to low protein and high fiber content compared to the S1 diet (Kewan, 2013; Allaoui et al., 2018). This finding is similar to previous studies that indicated that the inclusion of the olive cake or discarded dates declined the growth performance (Al-Dabeeb, 2005; Mioč et al., 2007; Allaoui et al., 2018). In addition, Abo Omar et al. (2012) mentioned that the inclusion of olive cake into Awassi lambs' diet did not affect the performance adversely. Mahgoub et al., (2007), reported that sheep fed date palm fronds gained less weight than those fed rhodes grass hay; which could be due to higher fiber content and lower protein content in palm fronds (Khattab et al., 2018).

The decline in growth rate in S2 and S3 diets groups could be attributed to lower dietary protein and high fiber contents compared to the S1 diet (Al-Dabeeb, 2005; Allaoui et al., 2018). More studies mentioned that incorporation the olive cake and date palm byproducts in lamb diets declined the digestibility of DM, OM, CP, NFE, and CF (Al-Dabeeb, 2005; García-Rodríguez et al., 2020), which support our results and could be attributed to high fiber and phenolic compounds that limit the availability of nutrients and affect the rumen microbiota negatively (Mioč et al., 2007; Awawdeh and Obeidat, 2013; Boufennara et al., 2016; Djamila and Rabah, 2016). Therefore, animals fed on such byproducts will require protein supplementation (Allaoui et al., 2018); also, feeding the animals on crude byproducts should be avoided (Mioč et al., 2007).

Lower digestibility of CP for both S2 and S3 than S1 (Table 3) might be due to higher condensed tannins in dates, which bind with protein and reduced its utilization. These results are similar to the findings that reported by Kewan (2013) who found that CP digestibility was 71.49 and 77.38 for lambs fed concentrate feed mixture with complete replacement of corn grains $(27.5 \%$ of the 
352 TMR) by discarded dates and control group, respectively. In addition, lower digestibility of NDF

353

354

355

356

357

358

359

360

361

362

363

364

365

366

367

368

369

370

371

372

373

374

375

376

377

378

379

380

381

382

383

384

385

386

387

388

389

390

391

for both S2 and S3 than S1 might be due to the soluble carbohydrate in the dates which has commonly been associated with rapid fermentation and subsequent depression of ruminal $\mathrm{pH}$. This finding was confirmed by Khattab et al. (2013) who found a linear decrease of NDF digestibly by increasing the dates inclusion rate.

\section{Rumen fermentation activity}

The improvement in rumen $\mathrm{pH}$ in S2 and S3 compared to S1 diet (Table 4) was also indicated in other studies on olive cake (Awawdeh and Obeidat, 2013; García-Rodríguez et al., 2020). In addition, the incorporation of the DPF in the $\mathrm{S} 3$ diet has increased the rumen $\mathrm{pH}$ compared to the other two groups. Khattab et al. (2018) reported that the inclusion of DPF in sheep's diet kept the rumen $\mathrm{pH}$ higher than sheep fed clover hay. The decline in rumen $\mathrm{pH}$ has a negative consequences on rumen fermentation (Dijkstra et al., 2012), which could be a positive point for using S3 diets in sheep feeding. The concentrate feed mixtures consist of rapidly fermentable carbohydrate that encourages the VFA production that declines the rumen $\mathrm{pH}$; in contrast, the higher content of ADF and NDF in S3 diets has neutralized the rumen $\mathrm{pH}$ (Asadollahi et al., 2016). The higher concentration of ammonia in $S 1$ is reflected by the higher dietary protein compared to other diets (Hamchara et al., 2018; Khattab et al., 2018; García-Rodríguez et al., 2020). Previous studies showed that incorporation of the DD in the animal diet decreased the protein content, rumen ammonia, and VFA; and did not affect VFA composition (Rajabi et al., 2017; Khezri et al., 2017). Another explanation for the linear decrease of ammonia is soluble sugars in the S2 and S3 capture more degradable nitrogen for microbial protein synthesis than the starch in S1 (Khezri et al., 2017).

The inclusion of OC, DD, and DPF in the diet changed the proportions of individual VFAs. Acetic and butyric acids were increased a long with a decrease in propionic acid (Table 4); this finding is in agreement with previous studies (De Visser et al.1998; Pallara et al. 2014; Asadollahi et al. 2016; García-Rodríguez et al., 2020) that revealed that higher dietary fiber stimulates the production of acetic acid and decrease the propionic acid due to increasing the activity of fibrolytic bacteria. The increase of butyrate in S2 and S3 groups was also obtained in previous studies on DD in sheep diets (Khezri et al.2017). Analyzing the effect of the feeding system on VFA production in the rumen is important as VFAs provide the animal with two-third of the energy supply of the ruminant (De Visser et al., 1998). Consequently, the production of meat and milk could be affected; for instance, the reduction in acetic to propionic ratio has a depressing effect on milk fat production (Sutton et al., 2003).

The activities of rumen enzymes and VFA production are the reflection of rumen microbial groups involved in rumen fermentation (Kamra et al., 2010; Latif et al., 2014). According to a study by Raghuvansi et al. (2007), the increase in the production of fibrolytic enzymes could be attributed to the higher numbers of fibrolytic bacteria. Our results indicated that group S1 showed higher enzymes activities (cellulase and xylanase), and a higher bacterial population followed by S3 (Table 4); this finding could be attributed to the presence of rapidly degradable carbohydrates and degradable nitrogen in S1 groups that stimulated bacterial growth

Peer) reviewing PDF | (2021:08:65038:1:0:NEW 11 Oct 2021) 
392 (Raghuvansi et al., 2007; Azizi-Shotorkhoft et al., 2018). Moreover, higher cellulase production 393 and bacterial population in S3 compared to S2 could be explained by the presence of molasses in

394

395

396

397

398

399

400

401

402

403

404

405

406

407

408

409

410

411

412

413

414

415

416

417

418

419

420

421

422

423

424

425

426

427

428

429

430

431

the diet and higher content of ADF, which agrees with the results of Azizi-Shotorkhoft et al. (2018) who indicated that the inclusion of molasses increased the cellulolytic activities. On the other hand, Khattab et al. (2018) reported that the inclusion of palm fronds in the animal diet reduced microbial protein due to low protein content that depresses microbial growth. The information about the effect of OC, DD, and DPF on rumen enzymes and the bacterial population is limited; an In vitro study conducted by García-Rodríguez et al. (2020) reported an increment in the bacterial density and reduction of the microbial protein by incorporation olive cake into the animal diet. Moreover, Dahlan, (2000) showed that goat fed oil palm fronds produced more ammonia, TVFA, acetic acid, cellulase and xylanase compared to goat fed rice straw, which supports our findings. Sheikh et al. (2019) revealed that feed digestibility and microbial activity were improved when degradable protein was added to the diet, which could explain the higher bacterial population and VFA production in S1.

\section{Diversity and composition of rumen bacteria}

Inclusion of the $\mathrm{OC}, \mathrm{DD}$, and DPF to the concentrate mixture has changed the diversity and composition of rumen bacteria (Tables 5 and 6 and Figures 1and 2), which is in agreement with previous studies on the olive cake (Pallara et al., 2014; Mannelli et al., 2018; García-Rodríguez et al., 2020). Mannelli et al, (2018) reported that rumen microbiota is highly affected by dietary composition especially the chemical compounds that have antimicrobial activities such as polyphenols observed in byproducts. At the same time, no available data on the effect of discarded dates and date palm fronds on the rumen microbial populations. The higher ASVs were linked with sheep group fed S3 diet that contains concentrate mixture plus forage, which is similar to findings obtained by (Petri et al., 2012; Rabee et al., 2020a). In this study, phylum Bacteroidetes and Firmicutes dominated the bacterial community; this finding was also reported in the rumen of lactating ewes fed olive cake (Mannelli et al., 2018), cattle (Petri et al., 2013), and camel (Rabee et al., 2020a).

Firmicutes were dominated by the family Ruminococcaceae and Lachnospiraceae (Tables 6 and 7), which is in agreement with results obtained by Rabee et al. (2020a). Members of family Ruminococcaceae degrade the hemicellulose, pectin, and cellulose present in the plant cell wall (Pettipher and Latham, 1979), which could explain the high representation of this family in S1 group that fed mixture with high-NDF content and group S3 that fed mixture with high-ADF and NDF contents. The decline in the relative abundance of Ruminococcaceae in S3 compared to S1 could be attributed to the presence of phenolic compounds in olive cake and date palm byproducts that affect fibrolytic bacteria (Khattab et al., 2018; Mannelli et al., 2018). According to Moumen et al, (2007), the optimal fermentation of lignocellulosic byproducts could be achieved by the addition of nitrogen and soluble carbohydrates to animal diets, which enhance rumen fermentation; this might illustrate the higher abundance of Ruminococcaceae in S1. Family Lachnospiraceae was dominated by genus Butyrivibrio that is cellulolytic bacteria and was overrepresented in S2 and S3 groups that fed diets with higher ADF that favors the

PeerJ reviewing PDF | (2021:08:65038:1:0:NEW 11 Oct 2021) 
432 cellulolytic bacteria (Pitta et al., 2014; Liu et al. 2017). The decline in the abundance of this

433

434

435

436

437

438

439

440

441

442

443

444

445

446

447

448

449

450

451

452

453

454

455

456

457

458

459

460

461

462

463

464

465

466

467

468

469

470

471

genus in S1 could be a result of lower fiber content (Mannelli et al., 2018). In addition, the genus Butyrivibrio is involved in the production of butyrate that explains the higher amount of butyrate in S2 and S3 (Bharanidharan et al., 2018). Otherwise, the decline of Butyrivibrio in S3 compared to S2 could be attributed to the presence of DPF that has higher polyphenol content (Boufennara et al., 2016; Mannelli et al., 2018). Anaerovibrio within family Veillonellaceae, has an essential role in the lipid metabolism and biohydrogenation in the rumen, this process is highly associated with concentrate content in animal diet that enhances the lipolysis (Prins et al., 1975). Consequently, the presence of this genus in the S1 and S2 groups is explained. Moreover, the disappearance of this genus from the S3 group could be linked to high fiber and polyphenols content due to the inclusion of date palm fronds that rich in both fiber and polyphenols (Mannelli et al., 2018; Boufennara et al ., 2016 ). Thus, the polyphenols have an adverse effect on some of the bacterial genera involved in biohydrogenation in the rumen (Frutos et al., 2004; He et al., 2007). Consequently, the quality of animal products (milk and meat) could be improved by the incorporation of polyphenols in ruminant diets (Pallara et al.2014). Vasta et al. (2010) reported that the inclusion of polyphenols in ruminant diets affects rumen metabolism, decreasing dietary protein degradation and fatty acid biohydrogenation through targeting specific groups of microorganisms.

At the phylum level, Bacteroidetes dominated the bacterial community in sheep groups, and its relative abundance varied between groups (Table 6 and Figure 2). This phylum was dominated by uncultured bacteria that are specialized in lignocellulose degradation (Naas et al. 2014), which explains the higher abundance in the S3 group. In addition, this phylum was dominated by Prevotella and RC9 gut_group, which is in agreement with a finding of Fouts et al. (2012) on cows. Prevotella can degrade starch, hemicelluloses, pectin and could produce propionate and xylanase in the rumen (Russell and Rychlik, 2001). Consequently, the overrepresentation of this genus in the $\mathrm{S} 1$ group is expected and explains the higher propionic acid and xylanase enzymes in the S1 group. RC9_gut_group was previously observed in camel and Rhinoceros gut and could have a role in the degradation of lignocellulose, which might illustrate its higher representation in group S3 (Mackenzie et al., 2015; Rabee et al., 2020b).

Furthermore, phylum Fibrobacteres was more abundant in group S3 (Table 7), which is an expected trend as this phylum is the major cellulolytic bacteria in the rumen (Ransom-Jones et al., 2012; Petri et al., 2012). Phylum Elusimicrobia and Verrucomicrobia were found higher in the S3 group; some members of these phyla have a role in fiber degradation, which supports our results (Hou et al. 2008; Herlemann et al. 2009; Lee et al. 2009). The members of Proteobacteria have a role in protein degradation (Liu et al. 2017).

\section{Conclusions}

Olive cake and date palm byproducts are available feed resources that could replace common concentrate feed mixture especially in case of limited availability or high price. Inclusion of OC, DD, and DPF affected animal performance and rumen fermentation parameters as well as microbial diversity and the relative abundance of rumen bacteria. Additionally, lignocellulolytic

PeerJ reviewing PDF | (2021:08:65038:1:0:NEW 11 Oct 2021) 
472 bacteria showed an increase in their relative abundance in the rumen of sheep fed byproducts.

473 The composition of the rumen bacterial community in Barki sheep is similar to other ruminant 474 animals.

\section{Acknowledgements}

476 We would like to acknowledge the Desert Research Center, Ministry of Agriculture and Land

477 Reclamation, Egypt. The authors gratefully acknowledge the Science and Technology

478 Development Fund (STDF), Egypt, Grant No. \# CB-2741 and No. \# BS 5667 for their support of

479 this paper for using different tools and instruments for molecular techniques.

\section{References}

481

482

483

484

485

486

487

488

489

490

491

492

493

494

495

496

497

498

499

500

501

502

503

504

505

506

507

508

509

Abdel-Moneim, A.Y., Ahmed, A.M., Ibrahim, M.M., Mokhtar, M.M. (2009). Flock dynamics of desert Barki sheep in relation to age structure. Tropical Animal Health and Production 41: 899905. doi: 10.1007/s11250-008-9277-4.

Abo Omar, J. M., Daya, R., and Ghaleb, A. (2012). Effects of different forms of olive cake on the performance and carcass quality of Awassi lambs. Animal Feed Science and Technology 171:167-172.

Abousoliman, I., Reyer, H., Oster, M., Muráni, E., Mourad, M., Rashed, M.A., Mohamed, I., Wimmers, K. (2020). Analysis of Candidate Genes for Growth and Milk Performance Traits in the Egyptian Barki Sheep. Animals 10:197. doi: 10.3390/ani10020197.

Al-Dabeeb, S. N. (2005). Effect of feeding low quality date palm on growth performance and apparent digestion coefficients in fattening Najdi sheep. Small Ruminant Research 57: 37-42.

Allaoui, A., Safsaf, B, Tlidjane, M., Djaalab, I., Mansour, H.D. (2018). Effect of increasing levels of wasted date palm in concentrate diet on reproductive performance of Ouled Djellal. breeding rams during flushing period. Veterinary World 11: 712-719. doi: 10.14202/vetworld.2018.712-719.

Almitairy,M.H., Alowaimer, M.H., El-Waziry, A.M., and Suliman, G.M. (2011). Effects of Feeding Discarded Dates on Growth Performance and Meat Quality Traits of Najdi Lambs. Journal of Animal and Veterinary Advances 10: 2221-2224. DOI: 10.3923/javaa.2011.2221.2224.

Alnaimy, A., Gad, A.E., Mustafa, M.M., et al. (2017). Using of citrus by-products in farm animals feeding. Open Access Journal of Science 1:58-67. DOI: 10.15406/oajs.2017.01.00014.

Annison, E. F. (1954). Studies on the volatile fatty acids of sheep blood with special reference to formic acid. Biochemical Journal 58:670-680.

AOAC. (1997). Association of Official Analytical Chemists. Official Methods of Analysis, 16th ed. AOAC, Arlington, VA, USA.

Asadollahi S., Sari M., Erafanimajd N., Chaji M., Mamoui M., Kiani A. (2016). Effects of partially replacing barley with sugar beet pulp, with and without roasted canola seeds, on performance, rumen histology and fermentation patterns in finishing Arabian lambs. Animal Production Science 58: 848-855.

Peer] reviewing PDF | (2021:08:65038:1:0:NEW 11 Oct 2021) 
510 Awawdeh, M. S., and Obeidat, B. S. (2012). Treated Olive Cake as a Non-forage Fiber Source

511 for Growing Awassi Lambs: Effects on Nutrient Intake, Rumen and Urine $\mathrm{pH}$, Performance, and

512 Carcass Yield. Asian-Australasian Journal of Animal Sciences 26:661-667.

513 http://dx.doi.org/10.5713/ajas.2012.12513.

514 Azizi-Shotorkhoft, A., Sharifi, A., Azarfar, A., and Kiani, A. (2018). Effects of different

515 carbohydrate sources on activity of rumen microbial enzymes and nitrogen retention in sheep fed

516 diet containing recycled poultry bedding. Journal of Applied Animal Research 46: 50-54. DOI:

$517 \quad 10.1080 / 09712119.2016 .1258363$.

518 Bailey, M.J., Biely, P., Poutanen, K. (1992). Interlaboratory testing of methods for assay of

519 xylanase activity. Journal of Biotechnology 23: 257-270.

520 Bharanidharan, R., Arokiyaraj, S., Kim, E.B., Lee, C.H., Woo, Y.W., Na, Y., et al. (2018)

521 Ruminal methane emissions, metabolic, and microbial profile of Holstein steers fed forage and

522 concentrate, separately or as a total mixed ration. PLOS ONE 13: e0202446.

$523 \mathrm{https} / / /$ doi.org/10.1371/journal.pone.0202446.

524 Boufennara, S., Bouazza, L., de Vega, A., Fondevila, M., Amanzougarene, Z., Lopez, S.

525 (2016). In vitro assessment of nutritive value of date palm by-products as feed for ruminants.

526 Emirates Journal of Food and Agriculture 28:695-703.

527 Callahan, B., McMurdie, P., Rosen, M., Han, A. W., Johnson, A. J.A., Susan, P.(2016).

528 DADA2: High-resolution sample inference from Illumina amplicon data. Nature Methods 13:

529 581-583. https://doi.org/10.1038/nmeth.3869.

530 Carberry, C. A., Kenny, D. A., Han, S., McCabe, M.S., Waters, S.M. (2012). Effect of

531 phenotypic residual feed intake and dietary forage content on the rumen microbial community of

532 beef cattle. Applied and Environmental Microbiology 78:4949-4958.

533 https://doi.org/10.1128/AEM.07759-11.

534 Carberry, C.A., Waters, S.M., Kenny, D.A., Creevey, C.J. (2014). Rumen methanogenic

535 genotypes differ in abundance according to host residual feed intake phenotype and diet type.

536 Applied and Environmental Microbiology 80: 586-594. https://doi.org/10.1128/AEM.03131-13.

537 Comeau, A. M., Douglas, G.M., Langille, M.G.I. (2017). Microbiome Helper: a Custom and

538 Streamlined Workflow for Microbiome Research. mSystems 2 : e00127-16; DOI:

$539 \quad 10.1128 / \mathrm{mSystems.00127-16.}$

540 Dahlan, I. (2000). Oil Palm Frond, a Feed for Herbivores. Corpus ID: 114797163

541 De Visser, H., Klop, A., van der Meulen, J., van Vuuren, A.M. (1998). Influence of maturity of

542 grass silage and flaked corn starch on the production and metabolism of volatile fatty acids in

543 dairy cows. Journal of Dairy Science 81:1028-35. doi:10.3168/jds.S0022-0302 (98)75665-6.

544 Denman, S.E., McSweeney, C.S. (2006). Development of a real-time PCR assay for monitoring 545 anaerobic fungal and cellulolytic bacterial populations within the rumen. FEMS Microbiology

546 Ecology 58: 572-82. DOI:10.1111/j.1574-6941.2006.00190.x.

547 Denman, S.E., Morgavi, D.P., and McSweeney, C.S. (2018). Review: The application of omics

548 to rumen microbiota function. Animal 12:233-245. doi:10.1017/R175173111800229X. 
549 Dijkstra, J., Ellis, J.L., Kebreab, E., Strathe, A.B., Lopez, S., France, J., Bannink, A. (2012).

550 Ruminal $\mathrm{pH}$ regulation and nutritional consequences of low pH. Animal Feed Science and

551 Technology 172: 22-33.

552 Djamila, D., and Rabah, A. (2016). Study of associative effects of date palm leaves mixed with

553 Aristida pungens and Astragalus gombiformis on the aptitudes of ruminal microbiota in small

554 ruminants. African Journal of Biotechnology 15: 2424-2433.

555 Elshazly, A. G., and Youngs, C. R. (2019. Feasibility of utilizing advanced reproductive 556 technologies for sheep breeding in Egypt.Part 1. Genetic and nutritional resources. Egyptian

557 Journal of Sheep \& Goat Sciences 14:39-52.

558 Estaún, J., Dosil, J., Al Alami, A., Gimeno, A., and A. e Vega, A.(2014). Effects of including

559 olive cake in the diet on performance and rumen function of beef cattle. Animal Production

560 Science 54: 1817-1821. http://dx.doi.org/10.1071/AN14352.

561 Fouts, D.E., Szpakowski, S., Purushe, J., Torralba, M., Waterman, R.C. (2012). Next generation 562 sequencing to define prokaryotic and fungal diversity in the bovine rumen. PLoS One 7:e48289. 563 https://doi.org/10. 1371/journal.pone.0048289.

564 Frutos, P., Hervás, G., Giráldez, F. J. \& Mantecón, A. R. (2004). Review. Tannins and ruminant 565 nutrition. Spanish Journal of Agricultural Research 2:191-202,

566 https://doi.org/10.5424/sjar/2004022-73.

567 García-Rodríguez, J., Mateos, I., Saro, C., González, J.S., Carro, M.D., Ranilla, M.J. (2020).

568 Replacing Forage by Crude Olive Cake in a Dairy Sheep Diet: Effects on Ruminal Fermentation

569

570 and Microbial Populations in Rusitec Fermenters. Animals 10:2235.

571 Ghose, T.K. (1987). Measurement of cellulase activities. Pure and Applied Chemistry 59: 257-

572268.

573 Gilbert, R.A, Townsend, E.M., Crew, K.S., Hitch, T.C.A., Friedersdorff, J.C.A., Creevey, C.J., 574 Pope, P.B., Ouwerkerk, D., and Jameson, E. (2020). Rumen Virus Populations: Technological

575 Advances Enhancing Current Understanding. Frontiers in Microbiology 11:450. doi:

$576 \quad 10.3389 /$ fmicb.2020.00450

577 Hamchara, P., Chanjula, P., Cherdthong, A., \& Wanapat, M. (2018). Digestibility, ruminal

578 fermentation, and nitrogen balance with various feeding levels of oil palm fronds treated with

579 Lentinus sajor-caju in goats. Asian-Australasian journal of animal sciences 31: 1619-1626.

580 https://doi.org/10.5713/ajas.17.0926.

581 He, Q., Lv, Y. \& Yao, K. (2007). Effects of tea polyphenols on the activities of alpha-amylase,

582 pepsin, trypsin and lipase. Food Chemistry 101:1178-1182.

583 https://doi.org/10.1016/j.foodchem.2006.03.020.

584 Henderson, G., Cox, F., Ganesh, S., Jonker, A., Young, W., Janssen, P.J. (2015). Rumen

585 microbial community composition varies with diet and host, but a core microbiome is found

586 across a wide geographical range. Scientific Reports 5:14567. DOI 10.1038/srep14567.

587 Henderson, G., Cox, F., Kittelmann, S., Miri, V.H., Zethof, M., Noel, S.J., Waghorn, G.C., and

588 Janssen, P.H. (2013). Effect of DNA extraction methods and sampling techniques on the

589 apparent structure of cow and sheep rumen microbial communities. PLoS One 8, e74787. 
590 Herlemann, D.P.R., Geissinger, O., Ikeda-Ohtsubo, W., Kunin, V., Sun, H., Lapidus, A., 591 Hugenholtz, P., Brune, A. (2009). Genomic analysis of "Elusimicrobium minutum", the first 592 cultivated representative of the phylum "Elusimicrobia" (formerly termite group 1). Applied and 593 Environmental Microbiology 70:2841-2849. DOI 10.1128/AEM.02698-08.

594 Hou, S., Makarova, K.S., Saw, J.H., Senin, P., Ly, B.V., Zhou, Z., Ren, Y., Wang, J., Galperin, 595 M.Y., Omelchenko, M.V., Wolf, Y.I., Yutin, N., Koonin, E.V., Stott, M.B., Mountain, B.W., 596 Crowe, M.A., Smirnova, A.V., Dunfield, P.F., Feng, L., Wang, L., Alam, M. (2008). Complete

597

598

599

600

601

602

603

604

605

606

607

608

609

610

611

612

613

614

615

616

617

618

619

620

621

622

623

624

625

626

627

628

629

genome sequence of the extremely acidophilic methanotroph isolate V4, Methylacidiphilum infernorum, a representative of the bacterial phylum Verrucomicrobia. Biology Direct 3: 1-25. https://doi.org/10.1186/ 1745-6150-3-26.

Iqbal, N., Khan, M.T., Amanullah, H., Din, I., Khan, H., Shah, M., Mushtaq, M.(2019). Effect of feeding different levels of discarded date palm (Phoenix dactylifera) on digestibility, milk yield, and composition in Damani sheep. Tropical Animal Health and Production51:2181-2186. doi: 10.1007/R11250-019-01919-w.

Jami, E., White, B.A., and Mizrahi, I. (2014). Potential role of the bovine rumen microbiome in modulating milk composition and feed efficiency. PLoS One 9:e85423.

Kamra, D.N., Agarwal, N., McAllister, T.A. (2010). Screening for compounds enhancing fiber degradation. In: Vercoe PE, Makkar HPS, Schlink AC, editors. In: In Vitro screening of plant resources for extra-nutritional attributes in ruminants: nuclear and related methodologies, Chapter 6. Dordrecht (the Netherlands): IAEA; p. 87-107.

Kepler, C. R. and Tove, S. B. (1967). Biohydrogenation of unsaturated fatty acids. 3. Purification and properties of a linoleate delta-12-cis, delta-11-trans-isomerase from Butyrivibrio fibrisolvens. The Journal of Biological Chemistry 242: 5686-5692.

Kewan, K.Z. (2013). Impact of total replacement of corn grains with discarded dates in concentrate diets on performance of growing Barki lambs. Egyptian Journal of Nutrition and Feeds 16: 169-180.

Khattab; I.M., A. M. Abdel-Wahed, K. Z. Kewan (2013). Effect of replacing corn grain with Azzawi dates in sheep diets on intake, digestibility, purine derivatives execration, microbial nitrogen and rumen fermentation. Egyptian Journal of Nutrition and Feeds 16: 243-252.

Khattab, M. S. A., and Tawab, A. M. A. (2018). In vitro evaluation of palm fronds as feedstuff on ruminal digestibility and gas production. Acta Scientiarum. Animal Sciences 40: e39586. https://doi.org/10.4025/actascianimsci.v40i1.39586.

Khezri, A., Dayani, O., Tahmasbi, R. (2017). Effect of increasing levels of wasted date palm on digestion, rumen fermentation and microbial protein synthesis in sheep. Journal of Animal Physiology and Animal Nutrition 101:53-60. doi: 10.1111/jpn.12504.

Kim, M., Morrison, M., Yu, Z. (2015). Status of the phylogenetic diversity census of ruminal microbiomes. FEMS Microbiology Ecology 76: 49-63.

Latif, M.R., Zahran, S.M., Ahmed, M.H., Zeweil, H.S., Sallam, S.M. (2014). Effect of feeding Saccharomyces Cerevisiae and/or Aspergillus Oryzae on nutrient utilization and rumen fermentation characteristics of sheep. Alexandria Journal of Agricultural Sciences 59:121-127.

PeerJ reviewing PDF | (2021:08:65038:1:0:NEW 11 Oct 2021) 
630 Lee, H.J., Jung, J.Y., Oh, Y.K., Lee, S.S., Madsen, E.L., Jeon, C.O. (2012). Comparative survey 631 of rumen microbial communities and metabolites across one Caprine and three Bovine groups, 632 using bar-coded pyrosequencing and $1 \mathrm{H}$ nuclear magnetic resonance spectroscopy. Applied and 633 Environmental Microbiology 78:5983-5993 DOI 10.1128/AEM.00104-12.

634 Lee, K., Webb, R.I., Janssen, P.H., Sangwan, P., Romeo, T., Staley, J.T., Fuerst, J. (2009). 635 Phylum Verrucomicrobia representatives share a compartmentalized cell plan with members of 636 bacterial phylum Planctomycetes. BMC Microbiology 9:5. https://doi.org/10.1186/1471-2180-96375.

638 Li, F., Li, C., Chen, Y., Liu, J., Zhang, C., Irving, B., Fitzsimmons, C. Plastow, G., and Guan, L. 639 (2019). Host genetics influence the rumen microbiota and heritable rumen microbial features 640 associate with feed efficiency in cattle. Microbiome 7:92. https://doi.org/10.1186/s40168-019641 0699-1.

642 Liu, K., Xu, Q., Wang, L., Wang, J., Guo, W., Zhou, M. (2017). The impact of diet on the 643 composition and relative abundance of rumen microbes in goat. Asian-Australasian Journal of 644 Animal Sciences 30:531-537.

645 Mackenzie, A.K., Naas, A.E., Kracun, S.K., Schuckel, J., Fangel, J.U., Agger, J.W., Willats, 646 W.G., Eijsink, V.G., Pope, P.B. (2015). A polysaccharide utilization locus from an uncultured 647 Bacteroidetes phylotype suggests ecological adaptation and substrate versatility. Applied and 648 Environemental Microbiology 81:187-195 DOI 10.1128/AEM.02858-14.

649 Mahgoub, O., Kadim, I. T., Al-Busaidi, M.H., Annamalai, K., Al-Saqri, N.M. (2007). Effects of 650 feeding ensiled date palm fronds and a by-product concentrate on performance and meat quality 651 of Omani sheep. Animal Feed Science and Technology 135: 210-221.

652 https://doi.org/10.1016/j.anifeedsci.2006.07.011.

653 Mannelli, F., Cappucci, A., Pini, F. et al.(2018). Effect of different types of olive oil pomace 654 dietary supplementation on the rumen microbial community profile in Comisana ewes. Scientific 655 Reports 8: 8455. https://doi.org/10.1038/s41598-018-26713-w.

656 Mioč, B., Pavić, V., Vnučec, I., Prpić,Z., Kostelić, A., Sušić,V .(2007).Effect of olive cake on 657 daily gain, carcass characteristics and chemical composition of lamb meat. Czech Journal of 658 Animal Science 52: 31-36.

659 Moumen, A., Yáñez-Ruiz, D.R., Martín-García, I., Molina-Alcaide, E.(2008). Fermentation 660 characteristics and microbial growth promoted by diets including two-phase olive cake in 661 continuous fermenters. Journal of Animal Physiology and Animal Nutrition 92:9-17. doi: 662 10.1111/j.1439-0396.2007.00685.x.

663 Naas, A.E., Mackenzie, A.K., Mravec, J., Schücke, J., Willats, W.G.T. et al. (2014). Do rumen 664 Bacteroidetes utilize an alternative mechanism for cellulose degradation? mBio 5:e01401665 e01414. https://doi.org/10.1128/mBio.01401-14.

666 Pallara, G., Buccioni, A., Pastorelli, R., Minieri, S., Mele, M., Rapaccini,S., Messini,A, Pauselli, 667 M., Servili, M., Giovannetti, L., and Viti, C. (2014). Effect of stoned olive pomace on rumen 668 microbial communities and polyunsaturated fatty acid biohydrogenation: an in vitro study. $B M C$ 669 Veterinary Research 10: 271. DOI 10.1186/R12917-014-0271-y 
670 Petri, R.M., Forster, R.J., Yang, W., McKinnon, J.J., McAllister, T.A. (2012). Characterization

671 of rumen bacterial diversity and fermentation parameters in concentrate fed cattle with and

672 without forage. Journal of Applied Microbiology 112:1152-1162. https://doi.org/10.1111/j.1365-

6732672.

674 Petri, R.M., Schwaiger, T., Penner, G.B., Beauchemin, K.A., Forester, R.J.,Mckinnon, J.J., 675 McAllister, T.A. (2013). Characterization of the core rumen microbiome in cattle during 676 transition from forage to concentrate as well as during and after an acidotic challenge. PLoS One 677 8: e83424

678 Pettipher, G.L., Latham, M.J. (1979). Characteris tics of Enzymes Produced by Ruminococcus 679 Jlavefaciens which Degrade Plant Cell Walls. Journal of General Microbiology 110: 21-27. 680 https://doi.org/10.1099/00221287-110-1-21

681 Pitta, D.W., Kumar, S., Veiccharelli, B., Parmar. N., Reddy, B., Joshi, C.G. (2014). Bacterial 682 diversity associated with feeding dry forage at different dietary concentrations in the rumen 683 contents of Mehshana buffalo (Bubalus bubalis) using 16S pyrotags. Anaerobe 25:31-41. DOI 684 10.1016/j.anaerobe.2013.11.008.

685 Prins, R. A., Lankhorst, A., van der Meer, P. \& Van Nevel, C. J. (1975). Some characteristics of 686 Anaerovibrio lipolytica a rumen lipolytic organism. Antonie van Leeuwenhoek 41: 1-11, $687 \quad 0.1007 / \mathrm{BF} 02565031$.

688 Rabee, A.E., Forster, R.J., Elekwachi, C.O., Kewan, K.Z., Sabra, E., Mahrous, H.A., Khamiss, 689 O.A., Shawket, S.M. (2020a). Composition of bacterial and archaeal communities in the rumen 690 of dromedary camel using cDNA-amplicon sequencing. International Microbiology 23:137-148. 691 doi: 10.1007/R10123-019-00093-1.

692 Rabee, A.E., Forster, R., Elekwachi, C., Sabra, E., Lamara, M. (2020b). Comparative analysis of 693 the metabolically active microbial communities in the rumen of dromedary camels under 694 different feeding systems using total rRNA sequencing. PeerJ 8:e10184 DOI $69510.7717 /$ peerj.10184.

696 Raghuvansi, S.K.S., Prasad, R., Tripathi, M.K., Mishra, A.S., Chaturvedi, O.H., Misra, A.K., 697 Saraswat, B.L., Jakhmola, R.C. (2007). Effect of complete feed blocks or grazing and 698 supplementation of lambs on performance, nutrient utilisation, rumen fermentation and rumen 699 microbial enzymes. Animal 1:221-226.

700 Rajabi, R., Tahmasbi, R., Dayani, O., Khezri, A. (2016). Chemical composition of alfalfa silage 701 with waste date and its feeding effect on ruminal fermentation characteristics and microbial 702 protein synthesis in sheep. Journal of Animal Physiology and Animal Nutrition 101:466-474. doi: 703 10.1111/jpn.12563.

704 Ransom-Jones, E., Jones, D.L., McCarthy, A.J., McDonald, J.E. (2012). The fibrobacteres: an 705 important phylum of cellulose-degrading bacteria. Microbial Ecology 63:267-281 DOI 706 10.1007/s00248-011-9998-1.

707 Romero-Huelva, M., Ramos-Morales, E., Molina-Alcaide, E. (2012). Nutrient utilization, 708 ruminal fermentation, microbial abundances, and milk yield and composition in dairy goats fed 709 diets including tomato and cucumber waste fruits. Journal of Dairy Science 95:6015-26. doi: $710 \quad 10.3168 /$ jds.2012-5573. 
711 Russell, J.B., Rychlik, J.L. (2001). Factors that alter rumen microbial ecology. Scienc 292:1119$712 \quad 1122$

713 Sheikh, G.G., Ganai, A.M., Sheikh, A.A., Mir, D.M. (2019). Rumen microflora, fermentation

714 pattern and microbial enzyme activity in sheep fed paddy straw based complete feed fortified

715 with probiotics. Biological Rhythm Research DOI: 10.1080/09291016.2019.1644019.

716 SPSS. (1999). Statistical package for social science "Release 15, SPSS INC, Chicago. USA.

717 Sutton, J.D., Dhanoa, M.S., Morant, S.V., France, J., Napper, D.J., Schuller, E. (2003). Rates of

718 production of acetate, propionate, and butyrate in the rumen of lactating dairy cows given normal

719 and low-roughage diets. Journal of Dairy Science 86:3620-33. doi: 10.3168/jds.S0022-

720 0302(03)73968-X.

721 Van Soest, P.J., Robertson, J.B., Lewis, B.A. (1991). Methods for dietary fibre, neutral detergent

722 Fibre and non-starch polysaccharides in relation to animal nutrition. Journal of Dairy Science 74:

$723 \quad 3583-3597$.

724 Vasta, V., Yanez-Ruiz, D.R., Mele, M., Serra, A., Luciano, G., Lanza, M., Biondi, L., Priolo, A. 725 (2010). Bacterial and protozoal communities and fatty acid profile in the rumen of sheep fed a 726 diet containing added tannins. Applied and Environmental Microbiology 76:2549-2555.

727 Walters, W., Hyde, E.R., Berg-Lyons, D., Ackermann, G., Humphrey, G., Parada, A., Gilbert,

728 J.A., Jansson, J.K., Caporaso, J.G., Fuhrman, J.A., Apprill, A., Knight, B. (2015). Improved 729 bacterial 16S rRNA gene (V4 and V4-5) and fungal internal transcribed spacer marker gene 730 primers for microbial community surveys. mSystems 1:e00009-15. doi:10.1128/

731 mSystems.00009-15

732 Wang K, Nan X, Tong J, Zhao G, Jiang L and Xiong B (2020) Steam Explosion Pretreatment

733 Changes Ruminal Fermentation in vitro of Corn Stover by Shifting Archaeal and Bacterial

734 Community Structure. Frontiers in Microbiology 11:2027. doi: 10.3389/fmicb.2020.02027.

735 Weimer, P. J., Shi, Y., and Odt, C.L. (1991). A segmented gas/liquid delivery system for

736 continuous culture of microorganisms on solid substrates, and its use for growth of

737 Ruminococcus flavefaciens on cellulose. Applied Microbiology and Biotechnology 36:178-183.

738 Wirth, R., Kádár, G., Kakuk, B., Maróti, G.,Bagi, Z., Szilágyi, Á., Rákhely, G., Horváth, J., and 739 Kovács, K.L. (2018). The Planktonic Core Microbiome and Core Functions in the Cattle Rumen 740 by Next Generation Sequencing. Frontiers in Microbiology 9:2285. doi:

741 10.3389/fmicb.2018.02285.

742 


\section{Table 1 (on next page)}

The components of experimental diets

Physical composition (\%) of the experimental rations. 


\begin{tabular}{|l|c|c|c|}
\hline \multirow{2}{*}{ Ingredients } & Farm ration & \multicolumn{2}{|c|}{ Experimental rations } \\
\cline { 2 - 4 } & $\mathrm{S} 1$ & $\mathrm{~S} 2$ & $\mathrm{~S} 3$ \\
\hline Corn granis & 22.5 & 10.0 & 10.0 \\
\hline Wheat grains & 22.5 & 0 & 0 \\
\hline Soybean meal & 11.0 & 17.0 & 17.0 \\
\hline CFM $^{*}$ & 44 & 0 & 0 \\
\hline Olive cake & 0 & 10.0 & 10.0 \\
\hline Discarded dates & 0 & 60.0 & 60.0 \\
\hline Mineral \&Vitamins & 0 & 0.3 & 0.3 \\
\hline Salt & 0 & 1.0 & 1.0 \\
\hline Lime stone & 0 & 1.3 & 1.3 \\
\hline Yeast & 0 & 0.3 & 0.3 \\
\hline Anti-fungi & 0 & 0.1 & 0.1 \\
\hline Total & 100 & 100 & 100 \\
\hline Roughage & 0 & 0 & + \\
\hline R: C ratio & $0 / 100$ & $0 / 100$ & $25 / 75$ \\
\hline
\end{tabular}
meal $12 \%$, soybean meal $10 \%$, wheat bran $17 \%$, vinas $3 \%$, lime stone $1.5 \%$, salt $1 \%$, premix $0.5 \%$. 


\section{Table 2 (on next page)}

Chemical analysis of experimental diets

Chemical composition of concentrate feed mixtures and Date palm frond 
1

2

3

\begin{tabular}{|l|c|c|c|}
\hline \multirow{2}{*}{ Items } & \multicolumn{2}{|c|}{ Concentrate feed mixture } & Date palm fronds \\
\cline { 2 - 3 } & $\mathrm{S} 1$ & $\mathrm{~S} 2$ & \\
\hline $\mathrm{DM}(\mathrm{g} / \mathrm{kg})$ & 924.1 & 954.5 & 986.7 \\
\hline $\mathrm{CF}(\mathrm{g} / \mathrm{kg} \mathrm{DM})$ & 48.0 & 95.1 & 298.4 \\
\hline $\mathrm{CP}(\mathrm{g} / \mathrm{kg} \mathrm{DM})$ & 200.0 & 185.2 & 75.3 \\
\hline $\mathrm{NDF}(\mathrm{g} / \mathrm{kg} \mathrm{DM})$ & 551.0 & 368.8 & 538.9 \\
\hline ADF $(\mathrm{g} / \mathrm{kg} \mathrm{DM})$ & 85.3 & 184.7 & 359.8 \\
\hline
\end{tabular}

4

5

6

7

8

9

10

11

12

13

14

15

16

17

18

19

20

21

22

23

Peer) reviewing PDF | (2021:08:65038:1:0:NEW 11 Oct 2021) 


\section{Table 3(on next page)}

Growth performance and digestibility

Effect of diet type on growth performance of growing lams and nutrients digestibility of the experimental rations. 


\begin{tabular}{|c|c|c|c|c|c|c|}
\hline \multirow{2}{*}{ Items } & \multicolumn{3}{|c|}{ Feeding systems } & \multirow{2}{*}{ SEM } & \multirow{2}{*}{ Mean } & \multirow{2}{*}{$P$ value } \\
\hline & S1 & $\mathrm{S} 2$ & S3 & & & \\
\hline \multicolumn{7}{|c|}{ Growth Experiment } \\
\hline Lamb No. & 12 & 12 & 12 & - & & - \\
\hline IBW, $\mathrm{kg}$ & 29.20 & 29.63 & 29.97 & 0.51 & 29.5 & 0.540 \\
\hline RGR*,\% & 66.02 & 54.43 & 57.78 & 1.02 & 59.4 & 0.001 \\
\hline Dry CFMI, g DM/ kg 0.75 & 106.9 & 112 & 70.68 & 0.38 & 96.45 & 0.001 \\
\hline Dry RghI, g DM/ kg ${ }^{0.75}$ & 0 & 0 & 23 & - & & - \\
\hline TDMI g/ kg 0.75 & 106.9 & 112 & 93.67 & 0.44 & 104.2 & 0.001 \\
\hline \multicolumn{7}{|c|}{ Digestibility Experiment } \\
\hline Rams No. & 3 & 3 & 3 & - & & - \\
\hline $\mathrm{BW}, \mathrm{kg}$ & 42.03 & 42.7 & 42.58 & 0.31 & 42.3 & 0.314 \\
\hline Dry CFMI/ kg ${ }^{0.75}$ & 61.91 & 66.02 & 46.69 & 0.73 & 58.2 & 0.001 \\
\hline Dry RghI / kg 0.75 & 0 & 0 & 16.01 & 0.38 & & - \\
\hline TDMI/ kg 0.75 & 61.91 & 66.02 & 62.70 & 0.91 & 63.5 & 0.041 \\
\hline DM digestibility $\%$ & 81.87 & 67.56 & 67.73 & 1.99 & 72.4 & 0.003 \\
\hline CP digestibility, $\%$ & 73.21 & 63.70 & 58.64 & 2.82 & 65.2 & 0.028 \\
\hline NDF digestibility, $\%$ & 86.58 & 60.74 & 60.17 & 2.26 & 69.15 & 0.001 \\
\hline
\end{tabular}

3 


\section{Table 4 (on next page)}

Rumen fermentation parameters and enzymes activites

Rumen $\mathrm{pH}$, ammonia nitrogen (NH3-N), total volatile fatty acid (VFA) concentration and VFA proportions, cellulase and xylanase enzymes, and bacterial population (Log10 copies/ $\mu \mathrm{L}$ DNA) in the rumen of Barki sheep under investigation (Mean $\pm \mathrm{SE}$ ) 


\begin{tabular}{|l|c|c|c|c|c|l|}
\hline \multirow{2}{*}{ Item } & \multicolumn{3}{|l|}{ Feeding systems } & \multirow{2}{*}{ SEM } & Mean & P Value \\
\cline { 2 - 5 } & S1 & S2 & S3 & & & \\
\hline Animal numbers & 3 & 3 & 3 & 9 & 9 & \\
\hline $\mathrm{pH}$ & 5.5 & 6.2 & 6.5 & 0.15 & 6.04 & 0.0001 \\
\hline NH3-N, mg/dl & 10.94 & 4.5 & 2.2 & 1.13 & 5.85 & 0.0001 \\
\hline TVFA, meq/dl & 8.2 & 5.4 & 5.5 & 0.5 & 6.4 & 0.006 \\
\hline Acetic acid, \% & 34.7 & 50.7 & 54.7 & 3.8 & 46.7 & 0.006 \\
\hline Propionic acid, \% & 62.0 & 44.3 & 36.5 & 4.0 & 47.6 & 0.002 \\
\hline Butyric acid, \% & 3.3 & 5.0 & 8.8 & 0.8 & 5.7 & 0.0001 \\
\hline A/P ratio & 0.56 & 1.14 & 1.50 & - & - & - \\
\hline Xylanase, IU/ml & 9.8 & 8.3 & 3.8 & 1.8 & 7.3 & 0.441 \\
\hline Cellulase, IU/ml & 8.7 & 6.7 & 8.3 & 1.0 & 7.9 & 0.731 \\
\hline BP*, Log 10 copies/ $\mu$ L DNA & 5.65 & 3.1 & 4.4 & 0.40 & 4.4 & 0.029 \\
\hline
\end{tabular}




\section{Table 5 (on next page)}

Alpha diversity indices

Summary of ASVs number, bacterial diversity indices in the rumen of Barki sheep under investigation (Mean $\pm \mathrm{SE}$ ). 
2

3

\begin{tabular}{|c|c|c|c|c|c|c|}
\hline \multirow[t]{2}{*}{ Diversity indices } & \multicolumn{3}{|c|}{ Feeding systems } & \multirow[t]{2}{*}{ SEM } & \multirow[t]{2}{*}{ Mean } & \multirow[t]{2}{*}{ P Value } \\
\hline & $\mathrm{S} 1$ & $\mathrm{~S} 2$ & S3 & & & \\
\hline Animal numbers & 3 & 3 & 3 & 9 & 9 & - \\
\hline Sequence reads $*$ & 21023 & 21785 & 22857 & 1113 & 21888 & 0.838 \\
\hline ASVs & 1517 & 2146 & 2479 & 242 & 2047 & 0.292 \\
\hline Chaol & 1519 & 2147 & 2481 & 242 & 2049 & 0.292 \\
\hline $\mathrm{ACE}$ & 1526 & 2157 & 2498 & 244 & 2060 & 0.289 \\
\hline Shannon & $5.34^{\mathrm{a}}$ & 6.85 & 7.07 & 0.3 & 6.4 & 0.008 \\
\hline Invsimpson & 112 & 458 & 657 & 105 & 409 & 0.081 \\
\hline Fisher & 254.8 & 471.5 & 572.3 & 63.5 & 432.9 & 0.095 \\
\hline
\end{tabular}

* Average/sample

5

6

7

8

9

10

11

12

13

14

15

16

17

18

19

20 


\section{Table 6 (on next page)}

Bacterial phyla in the sheep rumen

Relative abundance of bacterial phyla in the rumen of Barki Sheep under investigation. 


\begin{tabular}{|l|c|c|c|c|c|c|}
\hline \multirow{2}{*}{ Bacterial phyla } & \multicolumn{3}{|c|}{ Feeding system } & SEM & Mean & P value \\
\cline { 2 - 6 } & S1 & S2 & S3 & & & \\
\hline Animal number & 3 & 3 & 3 & & 9 & \\
\hline Bacteroidetes & 75.8 & 74.1 & 78.7 & 1.2 & 76.2 & 0.318 \\
\hline Firmicutes & 22.7 & 22.1 & 15.0 & 1.5 & 19.9 & 0.027 \\
\hline Proteobacteria & 0.05 & 0.8 & 1.03 & 0.24 & 0.6 & 0.262 \\
\hline Spirochaetes & 1.02 & 0.8 & 0.8 & 0.17 & 0.86 & 0.867 \\
\hline Actinobacteria & 0.34 & 0.13 & 0 & ND & ND & ND \\
\hline Fibrobacteres & 0.07 & 0.04 & 0.4 & 0.07 & 0.18 & 0.003 \\
\hline Planctomycetes & 0.06 & 0.8 & 1.15 & 0.2 & 0.76 & 0.041 \\
\hline Tenericutes & 0 & 0.9 & 1.47 & ND & ND & ND \\
\hline Cloacimonetes & 0 & $0.046(1 \mathrm{n})$ & 0.32 & ND & ND & ND \\
\hline Elusimicrobia & 0 & 0.12 & 0.37 & ND & ND & ND \\
\hline Kiritimatiellaeota & 0 & 0.09 & 0.36 & ND & ND & ND \\
\hline Verrucomicrobia & 0 & $0.05(1 \mathrm{n})$ & 0.17 & ND & ND & ND \\
\hline Synergistetes & 0.05 & 0.1 & 0.18 & 0.03 & 0.12 & 0.121 \\
\hline Lentisphaerae & 0 & 0 & 0.18 & ND & ND & ND \\
\hline
\end{tabular}




\section{Table 7 (on next page)}

Bcaterial genera in the sheep rumen

Relative abundances of dominant bacterial families and genera in the rumen of Barki sheep under investigation (Mean $\pm \mathrm{SE}$ ) 


\begin{tabular}{|c|c|c|c|c|c|c|c|}
\hline \multirow{2}{*}{ Family } & \multirow{2}{*}{ Genus } & \multicolumn{3}{|c|}{ Feeding system } & \multirow{2}{*}{ SEM } & \multirow[t]{2}{*}{ Mean } & \multirow[t]{2}{*}{$\mathrm{P}$ value } \\
\hline & & $\mathrm{S} 1$ & $\mathrm{~S} 2$ & S3 & & & \\
\hline Animal number & & 3 & 3 & 3 & 9 & 9 & \\
\hline \multicolumn{8}{|c|}{ Phylum: Actinobacteria } \\
\hline Bifidobacteriaceae & Bifidobacterium & 0.025 & 0 & 0 & ND & ND & ND \\
\hline \multicolumn{8}{|c|}{ Phylum: Bacteroidetes } \\
\hline Order:Bacteroidales & & 75.6 & 74.02 & 78.7 & 1.2 & 76.1 & 0.318 \\
\hline Family: Rikenellaceae & & 9 & 26.05 & 15.7 & 3.5 & 16.9 & 0.132 \\
\hline \multirow{3}{*}{ Rikenellaceae } & U29-B03 & 0.026 & 0.19 & 0.18 & 0.03 & 0.12 & 0.184 \\
\hline & NA & 0.056 & 0.14 & 0.06 & 0.01 & 0.08 & 0.007 \\
\hline & RC9 gut_group & 8.9 & 25.7 & 15.5 & 3.5 & 16.7 & 0.134 \\
\hline Prevotellaceae & & 59.8 & 30.6 & 21.5 & 6.6 & 37.3 & 0.015 \\
\hline \multirow{2}{*}{ Prevotellaceae } & Prevotella & 18.8 & 21.8 & 11.5 & 3.08 & 17.4 & 0.434 \\
\hline & Uncul_Prevotellaceae & 40.98 & 8.8 & 9.6 & 6.4 & 19.8 & 0.031 \\
\hline BS11 gut group & & 0 & 0.19 & 0.88 & ND & ND & ND \\
\hline \multicolumn{8}{|l|}{ Phylum: Firmicutes } \\
\hline Lactobacillaceae & Lactobacillus & 0.19 & 0 & 0 & ND & ND & ND \\
\hline Streptococcaceae & Streptococcus & 0 & 0.07 & 0.05 & ND & ND & ND \\
\hline \multirow{3}{*}{ Veillonellaceae } & Selenomonas & 8.94 & 1.3 & 0.2 & 3.5 & 3.5 & 0.011 \\
\hline & Anaerovibrio & 0.24 & 0.3 & 0 & ND & ND & ND \\
\hline & Schwartzia & 0.48 & 0 & 0 & ND & ND & ND \\
\hline \multirow[t]{2}{*}{ Acidaminococcaceae } & Succiniclasticum & 0.9 & 0.86 & 0.77 & 0.8 & 0.8 & 0.941 \\
\hline & Acidaminococcus & 0.23 & 0 & 0 & ND & ND & ND \\
\hline \multirow[t]{2}{*}{ Veillonellaceae } & Megasphaera & 0.036 & 3.78 & 0 & ND & ND & ND \\
\hline & Dialister & 0.1 & 0 & 0 & ND & ND & ND \\
\hline \multirow{5}{*}{ Erysipelotrichaceae } & Asteroleplasma & 0 & 0.023 & 0 & ND & ND & ND \\
\hline & UCG-004 & 0.07 & 0.5 & 2.1 & 0.34 & 0.9 & 0.008 \\
\hline & Sharpea & 1.27 & 5.6 & 0 & ND & ND & ND \\
\hline & Kandleria & 0 & 0.18 & 0 & ND & ND & ND \\
\hline & Catenisphaera & 0.15 & 0 & 0 & ND & ND & ND \\
\hline Ruminococcaceae & & 6.8 & 5.1 & 5.75 & 1.1 & 5.9 & 0.869 \\
\hline \multirow[t]{2}{*}{ Ruminococcaceae } & Saccharofermentans & 0 & 0.14 & 0.19 & ND & ND & ND \\
\hline & Papillibacter & 0 & 0 & 0.3 & ND & ND & ND \\
\hline Lachnospiraceae & & 1.9 & 5.2 & 4 & 0.56 & 3.7 & 0.021 \\
\hline \multirow{3}{*}{ Lachnospiraceae } & Acetitomaculum & 0.09 & 0 & 0 & ND & ND & ND \\
\hline & Butyrivibrio & 0.01 & 1.27 & 0.9 & 0.1 & 0.7 & 0.001 \\
\hline & Shuttleworthia & 0.3 & 0.2 & 0.23 & 0.05 & 0.25 & 0.816 \\
\hline Family XIII & & 0.43 & 0.57 & 0.23 & 0.07 & 0.4 & 0.225 \\
\hline \multirow[t]{2}{*}{ Family_XIII } & Mogibacterium & 0.16 & 0.03 & 0 & ND & ND & ND \\
\hline & Anaerovorax & 0 & 0.17 & 0.19 & ND & ND & ND \\
\hline Christensenellaceae & R-7 group & 0.02 & 1.13 & 1.1 & 0.2 & 0.77 & 0.002 \\
\hline \multicolumn{8}{|l|}{ Phylum: Elusimicrobia } \\
\hline Elusimicrobiaceae & Elusimicrobium & 0 & 0.03 & 0.17 & ND & ND & ND \\
\hline \multicolumn{8}{|c|}{ Phylum: Spirochaetes } \\
\hline Spirochaetaceae & Sphaerochaeta & 0.48 & 0.19 & 0.27 & 0.07 & 0.3 & 0.192 \\
\hline
\end{tabular}




\begin{tabular}{|c|c|c|c|c|c|c|c|}
\hline Spirochaetaceae & Treponema_2 & 1.59 & 0.67 & 0.35 & 0.2 & 0.8 & 0.251 \\
\hline \multicolumn{8}{|l|}{ Phvlum: Tenericutes } \\
\hline Anaeroplas & Anaeroplas & 0.01 & 0.06 & 0.4 & 0.07 & 0.15 & 0.081 \\
\hline
\end{tabular}




\section{Figure 1}

Principal coordinates analysis (PCoA).

Principal coordinates analysis of Barki sheep rumen bacterial community based on Bray-

Curtis dissimilarity. The analysis was performed between three sheep: black circles for samples of group S1, red triangles for samples of group S2, and green squares for samples of group S3. 


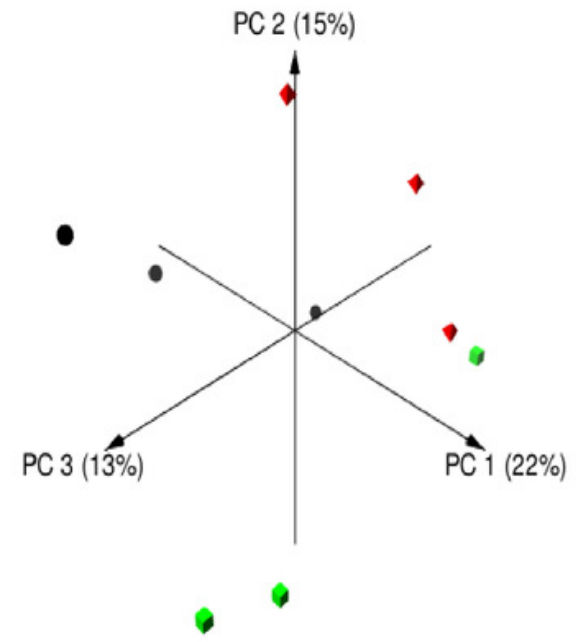


Figure 2

The relative abundance of dominant bacterial phyla.

The relative abundance of dominant bacterial phyla in the rumen of three sheep groups (S1, S2. S3). 


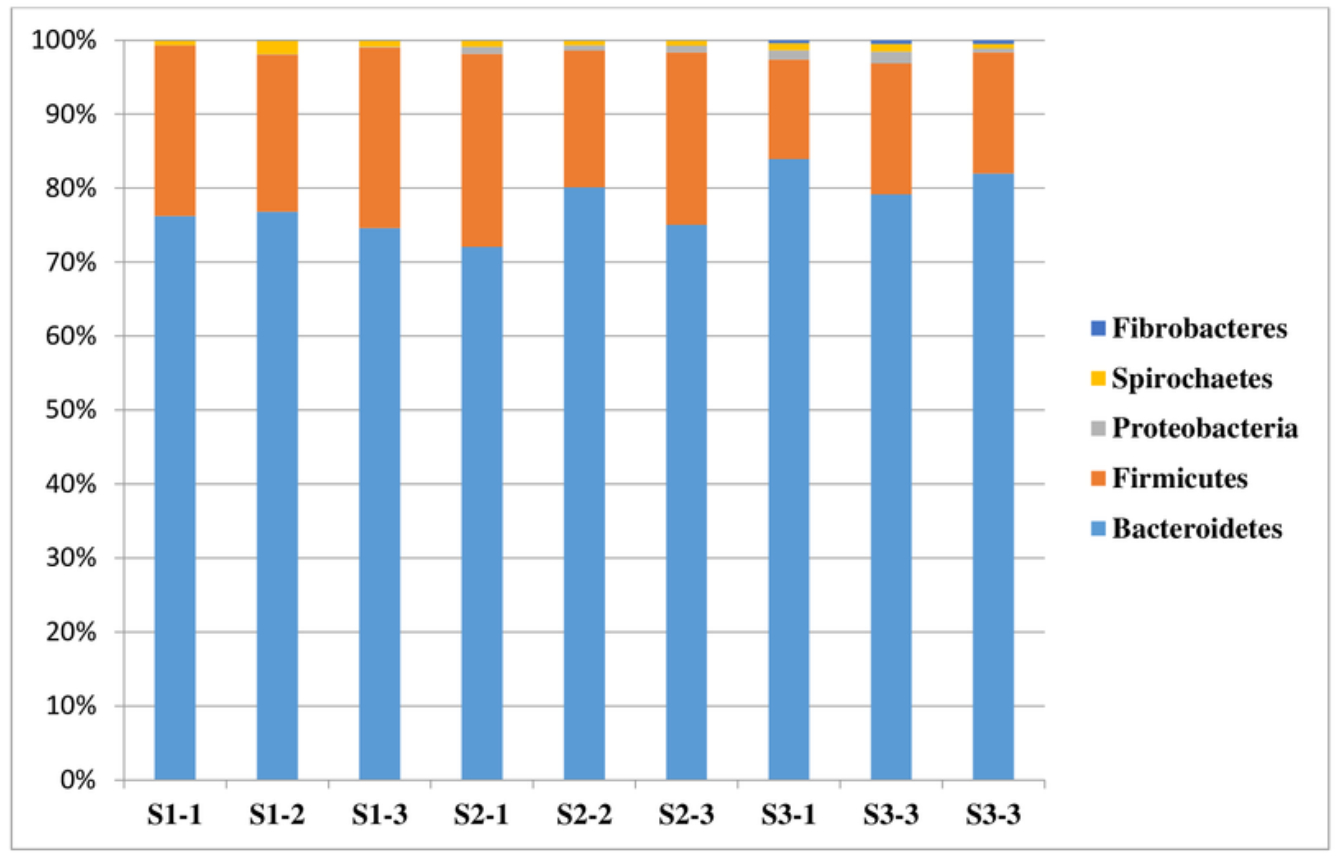

